\title{
ВТОРАЯ ГЕОЛОГИЧЕСКАЯ ЭКСПЕДИЦИЯ НА КОЛЬСКИЙ ПОЛУОСТРОВ - ПУТЕШЕСТВИЕ В.Н. БЁТЛИНГКА В РУССКУЮ ЛАПЛАНДИЮ
}

\author{
Петровский М.Н., Петровская Л.С. \\ Геологический институт КНЦ РАН, Anamumbl, petrovskiy@geoksc.apatity.ru
}

В 1839 г. по заданию Императорской Академии наук Финляндию и Русскую Лапландию посетили географ и геолог Дерптского университета Вильгельм Николаевич Бётлингк (1809-1841) и сотрудник Ботанического сада Александр Иванович Шренк (1816-1876). Основной задачей экспедиции было геогностическое обследование Кольского п-ова, а дополнительной - изучение морской и наземной флоры и фауны. От Петербурга до Колы В.Н. Бётлингк и А.И. Шренк путешествовали вместе, а в Коле экспедиция разделилась на две части. Дальнейшие исследования Кольского п-ова они проводили самостоятельными группами и вновь объединились только на Поное. Исторических работ посвящённых этой экспедиции, а также самому В.Н. Бётлингку (Вильгельм Николаевич - старший брат известного российского учёного филолога-индолога, академика Отто Николаевича Бётлингка (1815-1904) - прим. авт.), кроме краткого сообщения об этой экспедиции у Веры Фёдоровны Гнучевой (1890-1942) в её «Материалах к истории...» [2] и кратких упоминаний об экспедиции в геологической литературе $[1,6]$, нам обнаружить не удалось. Единственный источник об этой экспедиции - отчёт самого В.Н. Бётлингка, опубликованный на немецком языке в 1840 г. в «Научном бюллетене Императорской Академии наук» [12]. В то же время биография А.И. Шренка широко известна в истории науки, но всё же благодаря его работам по изучению флор Большеземельской тундры, Эстляндии и островов Финского залива, а не Кольского п-ова. О Кольской экспедиции он ничего не опубликовал [2].

Восьмого июня 1841 г. В.Н. Бётлингк скоропостижно скончался и, в связи с этим, 11 июня 1841 г. проходила Конференция Академии наук, где обсуждалась проблема получения Академией материалов Кольской экспедиции В.Н. Бётлингка. По-видимому, эти материалы в Академию так и не поступили [2]. Исходя из сказанного, Бётлингка и его экспедицию можно отнести к забытым в истории науки.

Путешествие В.Н. Бётлингка и А.И Шренка началось в первые дни мая 1839 г., с их отъезда почтовыми лошадьми из Петербурга в Гельсингфорс. Бётлингк не указывает конкретной даты отъезда, но точно указывает дату прибытия в Гельсингфорс - 7 (19) мая. Он пишет, что переезд занял несколько дней и снег в окружающих лесах почти растаял, но сохранился «на лесистых северных склонах возвышенностей вокруг Гельсингфорса» (здесь и далее по тексту цитаты из «Отчёта» В.Н. Бётлингка даны в переводе авторов статьи - прим. авт.). В Гельсингфорсе путешественники задержались на две недели, ждали, когда дороги Финляндии будут готовы для передвижения на север страны. Во время пребывания в Гельсингфорсе В.Н. Бётлингк занимался изучением гранитов-рапакиви, а А.И. Шренк исследованиями растительности окрестностей города.

Гельсингфорс В.Н. Бётлингк и А.И. Шренк покинули 21 мая (2 июня), отправившись на почтовых лошадях к северной оконечности Ботнического залива в г. Торнио, куда они благополучно прибыли 3 (15 июня), потому что: «Погода стояла прекрасная, а путь был лёгким, так как великолепная дорога вела нас вдоль плоского и преимущественно песчаного берега Ботнического залива до самого Торнио, здесь редко можно было увидеть приближающуюся скалу, состоящую из гнейсов, гранитов, кварцитов или глинистых сланцев. Ведь дорога проложена по береговым террасам Ботнического залива». В Торнио экспедиция была снабжена продовольствием, проводниками и переводчиком, знавшим шведский и финский языки, после чего 8 (20) июня отправилась в г. Кеми: «Таким образом, мы отправились в Кеми 8 (20) июня, чтобы двигаться дальше на северо-восток и пройти через лапландскую территорию в город Кола на Северном ледовитом океане». Из Кеми экспедиция отправилась на лодках вверх по течению р. Кемийоки к её истокам, где, преодолев водораздел, вышла в бассейн р. Туломы и далее, сплавившись по ней, прибыла 15 (27) июля в Колу. Путешествие было трудным, особенно тяжёлым выдался переход от Кемиярви до оз. Нотозера: «Последнее поселение на реке Кемийоки, состоящее из 5 крестьянских изб, называется Кежиемаярви (Кемиярви - прим. авт.) и находится выше 670, и всё же здесь финны ещё пытаются выращи- 
вать рожь и ячмень. В маленьких огороженных садах на сухих холмах вокруг своих домов они сажают овощи, которых вырастает иногда так много, что позволяет финнам время от времени заменять ими животную пищу. В течение последних 10 лет у них были неурожаи, а в этом году кукуруза была красивой, рожь стояла цветущей 29 июня (10 июля), ячмень был высоким и стоял с колосьями. Лошади, коровы и овцы паслись на берегу 80-метровой реки; лягушки квакали в лужах, а воздух был влажным и тёплым, $20^{\circ} \mathrm{C}$ ночью; всё это не давало воображению представить, что мы находимся на высоком севере. Только в этом последнем поселении мы узнали, что всё же сможем добраться до города Колы, и направление движения нами выбрано правильно, но расстояние до следующего летнего пребывания людей, уже русских лопарей, было очень значительным; мы узнали, что это расстояние составляет 250 вёрст по пустынному не населённому краю, но как в дальнейшем оказалось, и эта информация о расстоянии была неверной, оно было очень приуменьшено. При дальнейшем нашем продвижении на север река Кемийоки стала сужаться и с её берегов исчезли жилые дома, где можно было бы укрыться на ночь. Но всё более увеличивалось количество комаров и нас это стало сильно раздражать, единственным спасением от них был костёр из сырых веток, распространявший удушливый дым и хоть немного отгонявший от нас этих назойливых насекомых. Из плоской, болотистой и лесистой земли мы плыли по реке Кемийоки в направлении, указанном нам на картах финнами. Затем мы свернули в левый приток Кемийоки - ручей Вайя. Приближаясь к водоразделу, мы ожидали высоких берегов и обилия камней, но вместо этого берег становился всё ниже и ниже, пока мы не вышли в озеро, окружённое болотом; а перед нами, в 8 верстах к северо-востоку, лежала покрытая ивами и карликовой берёзкой, и сложенная гранито-гнейсами гора Сорсатунтури. В течение двух дней мы переносили наши лодки и вещи через Сорсатунтури к болоту, из которого начинался ручей Соттайоки, столь узкий, что в его русло едва по ширине помещалась лодка, но зато после четырёхчасового путешествия по этому ручью мы достигли реки Нуортийоки (р. Нота - прим. авm.) впадавшей в озеро Нотозеро, из которого вытекает река Тулома. Река Нуортийоки из-за множества порогов и водопадов в её русле не является судоходной. Мы выбрали трудный путь, и нам пришлось с большими усилиями в течение четырёх дней спускаться по реке Нуортийоки до Нотозера, где мы встретили 7 русских лопарей; они были первыми людьми, которых мы видели после длительного путешествия через этот пустынный край».

Весь переход от Кеми до Колы занял почти шесть недель, а научные результаты экспедиции были минимальными, что, по-видимому, было связанно с отсутствием возможности проводить детальные геологические наблюдения из-за трудностей путешествия: «Почти шесть недель прошли с тех пор как мы отправились от Ботнического залива, а пройденное расстояние, которое как мы предполагали, будет всего лишь 600 вёрст, оказалось протяжённостью около 900 вёрст. Переход через этот пустынный край занял гораздо больше времени, чем мы ожидали, а в научном смысле плоды его оказались минимальны. Эта пустыня сложена однообразными гнейсо-гранитами и реже роговообманковыми сланцами и кварцитами. Как мы обманулись в своих ожиданиях и идеях о Севере, по крайне мере в этой его области».

После прибытия в Колу 15 (27) июля В.Н. Бётлингк и А.И. Шренк разделились, геолог Бётлингк остался в Коле изучать её окрестности, а ботаник Шренк отправился исследовать побережье Русской Лапландии.

С начала В.Н. Бётлингк обследует район Колы и устанавливает, что окрестности города на обширной площади сложены гранитами и гнейсами «...перемежаемыми массами гранита и различных гнейсов. Гнейс и гранит являются доминирующими видами горных пород этой каменной страны». Он определяет, что граниты состоят из белого полевого шпата, серого кварца и небольшого количества чёрной слюды. Кроме того, характеризуя граниты, он указывает на то, что иногда наблюдается чередование тонких слоёв гранита и гнейса: «...так что обе породы нерасчленимы и должны считаться за одну, а грубая зернистость даёт не всегда различимую параллельную структуру». В современном понимании, это наиболее древний среди гранитоидов Кольского п-ова, архейский тоналит-трондьемит-гнейсовый комплекс. Согласно В.Н. Бётлингку, комплекс этих пород «...пересекается жилами гранитного пегматита, имеющими штокообразные вздутия...» и развит по всему побережью Кольского фьорда. В окрестностях Колы В.Н. Бётлингк впервые для Кольского п-ова описывает дайковый комплекс габбро-амфиболитов: «Здесь я впервые увидел массивные горнблен- 
диты и габбро, слагающие мощные пластообразные тела, включённые в скалы белого легко разрушающегося гранита». Изучая окрестности Колы, он отмечает, что город расположено на древней морской террасе и делает вывод о том, что Русская Лапландия испытывает поднятие: «На гранитных холмах вокруг города Кола имеются террасы, сложенные песком и глиной, и происходящие от более высокого стояния уровня моря, выше нынешнего уровня воды. На одной из этих террас расположен сам город, а на другой размещаются огороды с капустой и репой». На западном берегу Кольского залива В.Н. Бётлингк делает одно интересное и важное для истории геологии наблюдение: «Иногда между гнейсами у мыса Пинагорья наблюдаются мощные, более чем 200 футов ширины, массы очень плотного диорита, не разрушающегося отлично от вмещающих его гнейсов. Все эти диориты магнитные». Можно достаточно уверенно утверждать, что это первое описание железистых кварцитов на Кольском п-ове. Но на эту магнитную особенность горных пород не было обращено должного внимания ни самим Бётлингом, ни другими геологами - читателями его отчёта. Поэтому датой открытия железистых кварцитов на Кольском п-ове считается 1915 г., когда профессор Александр Алексеевич Полканов (1888-1963) по заданию Императорского Петроградского общества естествоиспытателей проводил геологическое изучение берегов Кольского фьорда и р. Тулома, и среди биотитовых серых гнейсов «...на восточном и западном берегах залива у мыса Пинагорьего...» обнаружил два коренных выхода магнетитовых сланцев и высказал предположение об аналогии и возможной связи найденных месторождений руды с месторождением Сёр-Варангер (открыто в 1902 г. - прим. авт.) в Норвегии [5]. Возможно, открытие В.Н. Бётлингка не было случайным. Ведь о том, что поморам и морякам издавна известно о неправильной работе компаса, и отклонении его стрелки на три и более румба к западу при прохождении кораблей между мысами Пинагорий и Мишуково, писалось во всех лоциях со времён М.Ф. Рейнеке [4, 7]. В XIX в. моряками-гидрографами было высказано правильное предположение, с чем может быть связана эта аномалия: «Склонение компаса в Кольском заливе представляет значительные уклонения, вероятно от присутствия железной руды в горах берегов его...». Маловероятно, что В.Н. Бётлингк не слышал о неправильной работе компаса в Кольском заливе от жителей Колы, тем более что обследования им берегов залива проводились с моря. Почему это находка магнитных пород не получила дальнейшего развития в работе Вильгельма Николаевича, мы уже не узнаем.

После обследования окрестностей Колы В.Н. Бётлингк решает, что теперь, в первую очередь, необходимо посетить п-ов Рыбачий. Вот как он об этом пишет: «Я решил обратиться, главным образом, к изучению Рыбачьего полуострова, который как мы знали ещё в Санкт-Петербурге, должен состоять из глинистого сланца, скалы которого так редко встречаются в Финляндии, а ведь им всегда сложены самые старые члены переходных гор».

Он установил, что п-ов Рыбачий сложен переслаиванием глинистых сланцев, различных песчаников, кварцитов и известняков. Здесь же он обратил внимание на то, что в ряде мест формация осадочных горных пород испытала интенсивные складчатые дислокации. В.Н. Бётлингк проводит тщательное изучение мест развития складчатости и устанавливает, что Кольский п-ов отделён от Рыбачьего рядом разрывных нарушений сбросового характера, по которым произошло опускание располагающейся по окраине Русской Лапландии формации осадочных горных пород, которые поэтому и сохранились от разрушения, но были смяты в складки: «С движением около границ гранитного массива связанно и появление целого ряда складчатых дислокаций в более молодой осадочной формации...». Этот вывод В.Н. Бётлингка о характере тектонических взаимоотношений Кольского и Рыбачьего п-вов, опередил своё время на полстолетия. В 1894 г. академик Александр Петрович Карпинский (1846-1936) анализируя взаимоотношения древнейших кристаллических образований Финляндии, Карелии и Кольского п-ова, пришёл к аналогичному выводу, что и В.Н. Бётлингк [3]. Он определил, что Кольский п-ов является горстом, ограниченным по периферии сбросами, вокруг которого располагаются понижения, совершившие по этим сбросам вертикальные перемещения и заполненные более молодыми осадочными породами, а разлом вдоль Мурманского побережья, отделяющий кристаллический щит от осадочного чехла, в современной геологической литературе называется разломом Карпинского.

Возвратившись с Рыбачьего в Колу, В.Н. Бётлингк нанимает поморскую лодью и отправляется изучать побережье восточной части Русской Лапландии. Во время своего плавания он отмечает, 
что весь Мурманский берег до устья Поноя сложен различными гранитами, разбитыми разломами на крупные блоки, а вдоль разломов море промыло длинные узкие ущелья. Вблизи устья Поноя граниты сменяются комплексом горнблендитов, хлоритовых сланцев и кварцитов, прорванным телами габбро; а южнее устья Поноя опять начинается область, сложенная гранитами.

От устья Поноя В.Н. Бётлингк продолжил свой путь к расположенным на Кандалакшском берегу Белого моря сёлам Варзуга и Кашкаранцы. На пути от Поноя до Варзуги экспедиция к берегу не приставала, информация о геологии этих мест у Бётлингка отсутствует. Это связанно с рядом объективных причин: началом осени - уже был сентябрь, время сильных штормов на Белом море; мелководностью моря около берегов, что не позволяло судну пристать к берегу. Плавание от Поноя до Варзуги для экспедиции оказалось исключительно тяжёлым: «Сначала был ужасный дождь, длившийся два дня, а пристать к берегу не было возможности, так как южное побережье Русской Лапландии является песчаным с редкими камнями. Море вблизи его мелководно и не имеет ни заливов, ни островов, а порты - это устья рек, в которые можно войти только во время максимального прилива, а мы их проходили задолго до этого времени. После дождя начался сильный ветер, длившийся четыре дня. Ветер был настолько сильный, что на четвёртый день его порыв сломал нам мачту, и чтобы спастись нам пришлось грести, но на наше счастье ветер вскоре прекратился. Вечером 3 (15) сентября мы достигли устья Варзуги, самой важной реки на этом побережье, но это было время отлива, и мы не смогли войти в него. Погода была исключительно хорошей, но ночью начался мороз. Этот мороз, долгие ночи и частые шторма убедили нас идти дальше на юг, несмотря на то, что нам хотелось исследовать побережье Лапландии. Поэтому утром мы, с попутным ветром, отправились дальше на юг, но ветер начал меняться и после обеда сменился на южный, и с юга море пошло высокими волнами, что вынудило нас повернуть обратно. К побережью, оставленному утром, мы вернулись через несколько часов. Наступающий вечер заставил нас принять решение искать убежище в деревне Кашкаранцы. Камни, торчащие повсюду и покрывающие дно мелкой бухты, не давали нам подойти к берегу, но пришла 9-я волна, восхитившая нас, и выбросила судно на камни. Только благодаря помощи сельских жителей мы и наше судно были спасены. В результате этого происшествия мы сильно промокли и замёрзли, но вскорости мы, расположившись в тёплых домах российских рыбаков, забыли о наших страданиях; мы были счастливы». Произошедшее кораблекрушение предоставило В.Н. Бётлингку возможность исследовать побережье Белого моря от Варзуги до п-ова Турий мыс. Он установил, что побережье на этом участке сложено слоистыми кирпично-красными песчаниками: «...слои песчаника, местами волнистые, слагают скалы, поднимающиеся до 120 футов в высоту. Им сложены и покрытые песком уступы террас, песок же на них образует передвигающиеся валы». Посетил Бётлингк и г. Турья на одноимённом полуострове, где вслед за Широкшиным совершил аналогичную ошибку, описав ийолит-уртиты Турьего как карбонатные кварциты: «...стены скал состоят из синевато-серого известково-кварцевого камня, который чрезвычайно прочен...». Геологическое строение основной части п-ова Турий мыс он характеризует как область, сложенную гранитами рапакиви: «На самом же полуострове есть много различных скальных образований сложенных гранитом; он очень крупный, похож на рапакиви и пронизан бесчисленными жилами диорита». Это первое в геологической литературе описание раннепротерозойского Умбинского комплекса чарнокитов-порфировидных гранитов, детальное изучение которых было выполнено геологами лишь в 1960-1970-х гг.

После посещения Турьего мыса, экспедиция В.Н. Бётлингка покинула Кольский п-ов: «Ранним утром 9 (21) сентября задувший северо-восточный ветер заставил нас поднять парус, покинуть землю Кандалакшского берега и отправиться к противоположному Карельскому берегу Белого моря». Экспедиция направилась в Сорокинскую губу к д. Сорока (на её месте сейчас расположен г. Беломорск - прим. авт.), чтобы пройти по Беломорскому тракту и сделать геогностический обзор между Белым морем и Онежским озером. По сути, В.Н. Бётлингк был первым, кто изучал геологию вдоль трассы будущего Беломора-Балтийского канала. Обзор этого путешествия мы не приводим, так как это тема отдельной статьи. Достигнув г. Повенец, В.Н. Бётлингк по Онежскому озеру добрался до Петрозаводска, откуда по первому санному пути отбыл в Санкт-Петербург.

В результате изучения геологии побережья Кольского п-ова В.Н. Бётлингк пришёл к важному выводу о происхождении гранитов и гнейсов. Граниты он считает, несомненно, плутоническими 
образованиями, сформировавшимися из «горячего кристаллического теста» выдавленного из недр Земли. А вот гнейсы, он предполагает, были изначально нептунического происхождения и аналогичны глинистым сланцам п-ова Рыбачьего: «...оба они показали своё отношение к нептуническим сущностям, которым они отвечают...». Но затем первичные сланцы испытали глубокие преобразования под воздействием тепла в местах, где граниты внедрились в них: «Тепло заставляет сланцы совместно со слоями окаменевшего песка изменяться в местах, где недавние нептунические образования сталкиваются с плутоническим вторжением в них кристаллического теста, и появляется гнейс как продукт глубокого преобразования нептуниановской формы». И в целом делает вывод о том, что: «Русская Лапландия, как ни одна страна, кроме может быть Северной Америки и Финляндии, не представляет такой обширной и подходящей области для наблюдений, где самые разные камни в разных условиях вступают в контакт друг с другом и где сама природа скалистых берегов Арктического моря предлагает геогносту много средств для проверки и отслеживания в природе его мнения».

О том, насколько важно для истории геологии заключение В.Н. Бётлингка о генезисе гранитов, гнейсов и сланцев, свидетельствующее о происходящем переломе в воззрениях российских геологов в конце первой трети XIX в., можно судить, если мы вспомним, что на конец XVIII - первую половину XIX вв. приходится время наиболее острых споров нептунистов и плутонистов о происхождении изверженных пород, образовании и эволюции Земли.

Нептунисты считали, что все геологические процессы на Земле обусловлены действием воды, все минералы и горные породы, не исключая гранита и базальта, образовались из морской воды. Граниты, гнейсы, базальты и другие кристаллические породы сформировались на дне океана путём химического осаждения и из них сложены «первозданные горы». Глинисты сланцы, песчаники, известняки и др. осадочные породы сформировались путём механического и химического осаждения продуктов разрушения пород «первозданных гор». Согласно воззрениям нептунистов, сначала, при разрушении «первозданных гор», образуются «переходные горы» прилегающие к «первозданным», а затем «флёцовые (слоисты) горы». Теория нептунизма получила полное развитие в работах профессора Фрайберской горной академии Абраама Вернера (1750-1817) [11]. Нептунисты полностью игнорировали уже имевшиеся к тому времени данные о значительных движениях земной коры, отрицали постоянное преобразующее воздействие находящихся внутри Земли раскалённых масс на земную поверхность. Согласно их представлениям, магматические явления никакого значения в истории Земли не имели. А вулканизм А. Вернер объяснял горением каменного угля в недрах.

Теория плутонизма опиралась на представления о существовании центрального огня внутри Земли. Весьма полно она разработана шотландским естествоиспытателем Джеймсом Геттоном (1726-1797) и изложена в книге «Теория Земли» (1795). По представлениям плутонистов, причина образования гор и поднятия материков - действие подземного огня. Материки постепенно разрушаются от действия атмосферных осадков, ветра, текущей воды и других агентов. Продукты их разрушения сносятся в океан, где и отлагаются на дне, а затем затвердевают, образуя осадочные породы. Граниты, базальты и другие кристаллические породы формируются из огненно-жидкой массы, а гнейсы и кристаллические сланцы являются метаморфическими образования, сформировавшимися в результате сплавления осадочных пород под действием высокой температуры от близости подземного огня. Плутоническая теория сначала не получила той популярности, какой обладала нептуническая теория Вернера, талантливого профессора и оратора, к нему стекались слушатели со всей Европы. Распространению плутонической теории мешала резкая оппозиция со стороны учёных и церкви, видевших в ней покушение на библейскую картину творения мира. Нептуническая теория церкви не противоречила и ею поддерживалась. В начале XIX в. нептуническая теория пришла в Россию, и русские геологии большей частью приняли её как господствующую геологическую теорию. В Горном кадетском корпусе и Московском университете геогнозия преподавалась по Вернеру, учебник «Геогнозия» академика Александра Фёдоровича Савостьянова (1771-1824), изданный в 1810 г. и рекомендованный в качестве пособия для университетов, представлял собой перевод лекций Вернера на русский язык. Распространению нептунической теории пытались противостоять академик Василий Михайлович Севергин (1765-1826), профессора Московского университета Иван Алексеевич Двигубский (1771-1840) и Александр Алексеевич Иовский (1796-1857). В 1825 г. буду- 
щий академик и сторонник нептунизма Дмитрий Иванович Соколов (1788-1852) в «Горном журнале» публикует статью «Успехи геогнозии» [9], в которой утверждает, что в борьбе нептунистов и плутонистов первые безоговорочно победили: «Учение Вернера осталось победителем и возвратилось с поля чести украшенным новыми совершенствами, плодами его подвигов». В этой же статье о теории плутонизма и его сторонниках он написал: «Подобные догадки людей, даже самые остроумные, коль скоро оные несогласны со Священным Писанием, должны быть отвергаемы как сущая ложь: ибо токмо свидетельство Господне верно, и истина Господня пребывает во век». А теорию Лапласа о происхождении Земли охарактеризовал как «...исчадие разгоряченного воображения, которое, вместе с подобными им теориями Райя, Шейцера... облечёно в одежду науки...». Накал страстей в споре был высок, об этой борьбе очень метко высказался во второй половине XIX в. профессор Московского университета, геолог и анатом Григорий Ефимович Щуровский (1803-1884), учившийся в 1820-х гг. в Московском университете и наблюдавший это противоборство: «Столкновение этих теорий сопровождалось таким ожесточением, такой непримиримостью, которое можно сравнить только с борьбою воды с огнём, тех стихий, которые ими защищались» [8].

Признание и распространение идей плутонистов шло очень медленно, но уже к концу 1830-х гг. в среде русских геологов начинает происходить перелом в воззрениях. В ходе практических работ, проводившихся в самых разных геологических условиях на громадной территории России, русские горные инженеры имели возможность на огромном фактическом материале проверить свои теоретические представления, что дало им возможность вскоре убедиться в ошибочности основных положений нептунизма и начать переходить на сторону плутонической теории. Изменил свои взгляды и не побоялся признать ошибочность своего первоначального мнения и академик Д.И. Соколов. В «Курсе геогнозии» [10] он определённо утверждал, что Земля некогда находилась в огненножидком состоянии и ныне под «твёрдой скорлупой Земли» находится жидкое ядро, а горы образуются в результате «воздымания» земной коры из-за вторжения плутонических масс. Наглядным примером происходившего перелома являются и выводы В.Н. Бётлингка об образовании гранитов и гнейсов Русской Лапландии.

\section{Литература}

1. Геология CCCP. Т. XXVII. Мурманская обл. Ч. 1. / Гл. ред. Л.Я. Харитонов. М.: Госгеолтехиздат, 1958. $714 \mathrm{c}$.

2. Гнучева В.Ф. Материалы к истории экспедиций Академии наук в XVIII и XIX веках (хронологические обзоры и описания архивных материалов). М.: Изд-во АН СССР, 1940. 310 с.

3. Карпинский А.П. Очерки геологического прошлого Европейской России (статьи 1883-1894 гг. с дополнениями и примечаниями). Петроград: Военная тип., 1919. 158 с.

4. Морозов Н.В. Лоция Мурманского берега Северного Ледовитого океана от островов Вардэ до Белого моря. С.-Пб.: Тип. Морского мин-ва, 1901.712 с.

5. Полканов А.А. О находке железных руд в Русской Лапландии // Тр. Имп. Петрогр. об-ва естествоисп. Т. 46. Вып. 1. № 7-8. 1915. С. 248-250.

6. Полканов А.А. Геолого-петрологический очерк Северо-Западной части Кольского п-ова. Ч. І. Л.-М.: Изд-во АН СССР, 1935. 564 с.

7. Рейнеке М.Ф. Гидрографическое описание Северного берега России. Ч. ІІ. Лапландский берег. Составлено капитан-лейтенантом М. Рейнеке в 1833 г. Изд. 2-е Гидрограф. деп. С.-Пб.: Тип. Морского мин-ва, 1878. $279 \mathrm{c}$.

8. Речи и статьи Григория Ефимовича Щуровского, собранные и изданные ко дню юбилея Обществом любителей естествознания и комитетом Политехнического музея. (Изв. Имп. об-ва любителей естествознания, антропологии и этнографии. Т. ХХХІІІ. Вып. 2). М.: Тип. М.Н. Лаврова и Кㅇ 1878. 507 с.

9. Соколов Д.И. Успехи геогнозии // Горный ж-л. Кн. 1. № 1. 1825. С. 3-27.

10. Соколов Д.И. Курс геогнозии. Ч. 3. СПб.: Тип. Э. Праца и К, 1839. 324 с.

11. Шафрановский И.И. А.Г. Вернер. Знаменитый минералог и геолог. 1749-1817. Л.: Наука, 1968. 198 с.

12. Böhtlingk W. Bericht einer Reise durch Finnland und Lappland // Bull. Sci. publie par l'Académie Impériale des Sciences de Saint-Pétersbourg. 1840. V. 7. N 8, 9. P. 107-129; № 13, 14. P. 191-208. 